\title{
Preface
}

\section{Diagnosis and Management of Neck Masses}

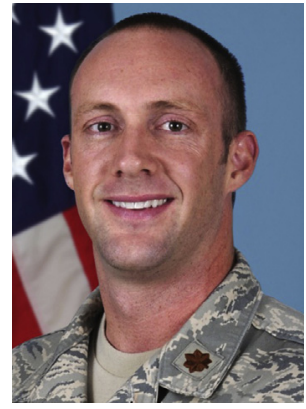

David E. Webb, Maj, USAF, DC

Editor

\section{Mad about surgery}

The only people for me are the mad ones, the ones who are mad to live, mad to talk, mad to be saved, desirous of everything at the same time, the ones who never yawn or say a commonplace thing, but burn, burn, burn like fabulous yellow roman candles exploding like spiders across the stars.

-Jack Kerouac, On the Road

\section{Good hands, heads, and hearts}

When I was an Oral and Maxillofacial Surgery (OMS) resident, I constantly perseverated about and obsessed over my quest to develop "good hands." I started shaving and brushing my teeth with my nondominant hand, tied silk knots on every imaginable surface, and practiced "palming" a needle driver everywhere I went. Recognizing that outstanding manual dexterity is obviously a must to successfully operate the neck, it is clearly the case that good hands alone don't guarantee good outcomes. In addition to good hands, fellowship training further reinforced the importance of developing a "good head" (ie, cognitive analysis). I learned that our patients are our "books," that each patient is unique and as such requires an individual approach based on guiding principles, and that the answer to every question begins with "It depends-." Feeling well equipped as a new attending, I was surprised to discover that I still lacked a critical component of care-a truly caring heart. The powerful combination of good hands, heads, and hearts results in surgeons who are truly mad about surgery and whose results are never commonplace, but "burn, burn, burn like fabulous yellow roman candles exploding like spiders across the stars" (On The Road). Let us be mad about surgery!

\section{Exciting times}

These are exciting times for Oral and Maxillofacial Surgeons. OMS Head and Neck fellowship opportunities have increased over $150 \%$ in the last decade (with more on the horizon). Also, an estimated $40 \%$ of current OMS training programs provide OMS-based exposure to head and neck surgery. This exposure not only improves our surgical prowess, but, owing to the significant comorbidities that routinely accompany these patients, we further our ability to understand and apply medicine, refine our airway expertise, and interact with other providers.

This issue of Oral and Maxillofacial Surgery Clinics of North America presents contributions from a number of experts within our specialty whom I deeply respect. It not only honors many of the pioneers of OMS-based neck surgery but is also an expression of a vital up-and-coming generation of OMS head and neck surgeons. The issue begins with a discussion of contemporary imaging modalities used in evaluating neck masses. Subsequent articles address pediatric patients, soft tissue tumors as well as neck masses from a variety of etiologies including infectious, hematopoietic, endocrine, salivary, vascular, and metastatic disease. 
The issue concludes with a discussion of the reconstruction of cervical defects.

\section{Thanks}

I want to express thanks to all who have assisted in this work, from past and current colleagues to residents who continue to challenge me. I am also greatly indebted to my wife and parents. Last, thanks be to God for allowing me the privilege of treating His children and allowing me to enjoy it so much!
David E. Webb, Maj, USAF, DC Department of Oral and Maxillofacial Surgery David Grant USAF Medical Center Travis AFB, CA, USA

David Grant USAF Medical Center 101 Bodin Circle/SGDD Travis AFB, CA 94535, USA

E-mail address: david.webb.5@us.af.mil 